\title{
Politics, Policy, Settlers, and Consequences for Canadian Prairie Grasslands: A Range Management Perspective
}

\section{By Arthur Bailey, Michael P. Schellenberg, Duane McCartney, and Patricia Bailey}

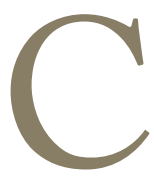

an you imagine the Northern Great Plains with no native prairie grasslands? In this paper, we consider the politics, assumptions, biases, and policies that led to the rapid conversion by homesteaders of $80 \%$ of the Canadian prairie natural grasslands into cropland, primarily for wheat production.

The policies implemented by the Canadian government from the 1870s to 1930, and the "great land rush" of settlers who enthusiastically plowed the prairie grasslands to grow annual crops, removed too high of a proportion of the native prairie grassland. The natural grasslands, a part of the Northern Great Plains, extended across southern Manitoba, Saskatchewan, and Alberta. They originally covered about 61 million ha. ${ }^{1}$ Now the residual grasslands occupy about 11 million ha. About 50 million ha of natural grasslands were plowed under in favor of wheat and other crops.

These residual natural grasslands are rangelands that now occupy only about $20 \%$ of the area. These grasslands are hardy, drought resistant, and evolved over millions of years; they are highly adapted to the climate., ${ }^{2,3}$ They originated from an Arctotertiary flora over a period of about 35-50 million years. These grasslands are equally important for their life-renewing essential ecological services, for habitat and forage for domestic livestock and wildlife on ranches, parks, and military facilities, and for conservation of rare and endangered ecosystems and species. ${ }^{4}$

The prairie climate is continental and highly variable. The Rocky Mountains to the west act as a barrier to the prevailing northwesterly flow of weather systems. Drought is a frequent visitor to the prairies. Tree-ring studies reveal that, over the past 400 years, two major droughts per century were normal. ${ }^{5}$ The high frequency of drought on the prairies, and particularly in the Dry Mixed Grass prairie ecoregion, is important for ranchers and park and wildlife range managers to recognize and address in their management planning.

There are five prairie ecoregions: Dry Mixed Grass, Mixed Grass, Foothills Fescue, Parkland Northern Fescue, and Tall Grass prairie (Fig. 1). The most favored soils for annual crop production are Black, Dark Gray, and Dark Brown chernozem and solod (Fig. 2). Consequently, these areas have the lowest percentages of natural grassland remnants today. Currently, the natural grasslands in the Tall Grass, Parkland Northern Fescue, and Mixed Grass prairie ecoregions are considered to be endangered, rare, or threatened ecosystems. In many areas, less than $1 \%$ of the natural grasslands remain.

\section{Grazing Managers in Pre-History}

The ancient natural grasslands of the Great Plains evolved along with the climate and grazing animals over millions of years. As climate fluctuated over the centuries, so did the areas of the ancient grassland, grazing animals, and the soils. About a million years ago, the most profound of climatic extremes arrived and remained until the glaciers melted. Like slow-moving bulldozers, the four or more giant continental glaciers pushed across the Canadian prairies, ripping out vegetation and soil and leaving behind glacial moraine, glacial lakes, ice dams, and eventually giant rivers during the ice melts. As the glaciers receded, the initial colonizers were tundra plants, and then as the temperature increased, cool season grasses again covered the plains. As the grazing animals returned, so also did aboriginal man. ${ }^{6,7}$

For millions of years, grazing, drought, and fire influenced the grasslands of the prairies. Drought and fire both strongly impacted the formation of ancient natural grasslands. Grazing has always been a part of the Great Plains grasslands. During the ice age, there were horses, 


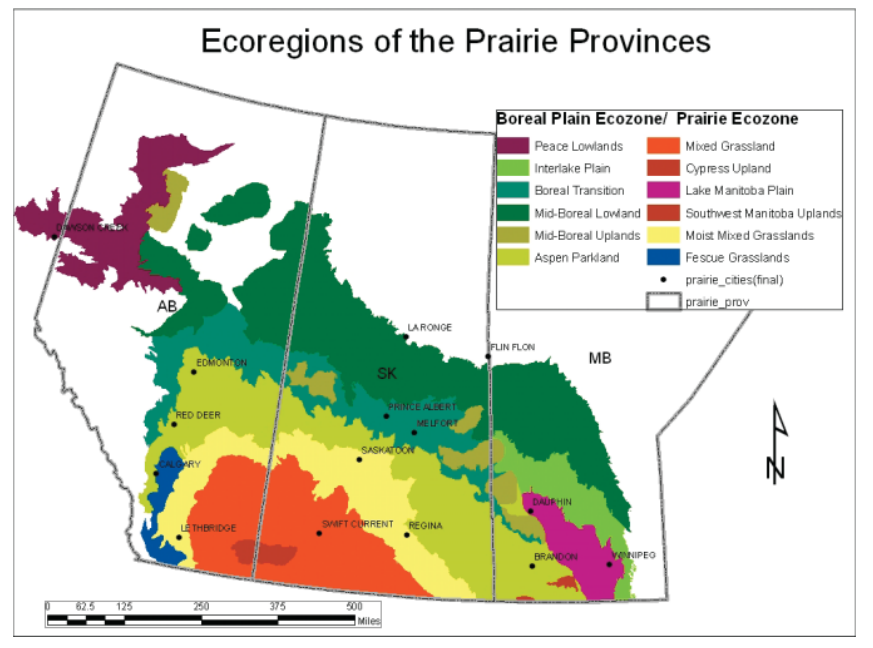

Figure 1. Ecoregions of the prairie provinces of Canada (from http:// www4.agr.gc.ca/resources/prod/img/pfra/shelterbelt/pfra_shelterbelt_ spec_rec_052.gif).

camels, and mammoths, but later, bison became the dominant grazer on the Northern Great Plains grassland ecosystems. ${ }^{6}$ Overgrazing occurred when the populations of grazing animals exploded, when there was drought, and when too many fires removed too much of the forage resource. These factors also would have reduced rangeland ecological health. Subsequently, many grazers would have died due to starvation, lack of water, or disease. Afterward, for a period of years, the rangelands would gradually have recovered to a healthier state because of the reduced grazing pressure.

Aboriginal peoples inhabited the Great Plains at least 11,000 years ago. ${ }^{7,8}$ They used the plains grazing animals for food, clothing, fiber, ritual purposes, and shelter. These aboriginal managers learned to manipulate both the grazing animals and the natural grasslands using fire, herding, buffalo jumps, and buffalo pounds. Aboriginal communities survived for millennia in the challenging environment of the Northern Great Plains because they learned to adapt to changing conditions. ${ }^{9}$

\section{Historical Managers}

On the Canadian Northern Great Plains some of the aboriginal peoples represented were Blackfoot (Piegans, Bloods, and Siksikas), Assiniboine, Crow, and Cree. ${ }^{9}$ Bison were a principle food source and a vital aspect of the economy of the native peoples of the prairies. ${ }^{10,11}$ Each aboriginal community interacted with its neighbors through trading, diplomacy, and warfare. ${ }^{12}$ Changing circumstances affected the First Nations. The arrival of the horse and gun into the prairie communities came at different times. Then came the establishment of fur-trading posts and competing interests of Americans, British, and eastern Canadian travelers and traders. ${ }^{12}$ The aboriginal peoples reacted to the transformed conditions by analyzing the situation on the ground and acting to advance their own

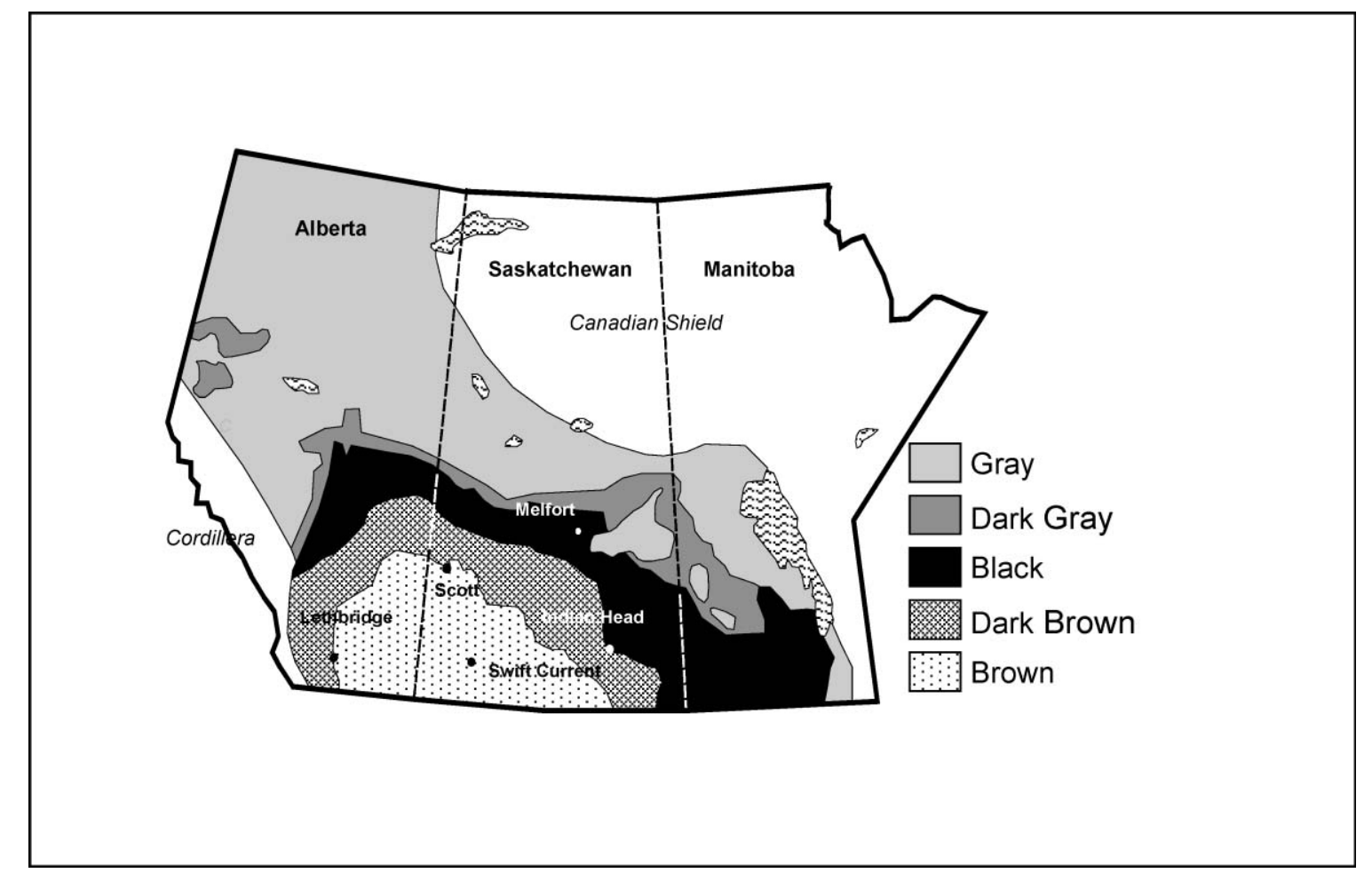

Figure 2. Soils map of the prairie provinces of Canada. 
interests. However, some of the whites exposed these plains peoples to unfamiliar contagious diseases. Smallpox in particular decimated these aboriginal communities, ${ }^{9,13}$ thus reducing their ability to defend their territory from encroaching Europeans.

The First peoples of the Canadian prairies were skilled land managers, and they possessed a highly developed knowledge of the Great Plains ecosystems. The Native people's rangeland management practices were part of a comprehensive strategy to promote the interests and security of bands or groups of bands. ${ }^{14}$ In Alberta, the surveyor Peter Fidler spent a winter in 1792-1793 with Piegan Indians. ${ }^{15}$ $\mathrm{He}$ recorded how they managed the rangeland and the wildlife using methods unfamiliar to Europeans. Fidler quickly learned that his fear of fire was out of step with their knowledge and skills. The Piegans, Bloods, and Siksikas and many other groups had learned the benefits and risks associated with managed prairie fire. Lewis described the many reasons why aboriginal peoples used controlled burning as a landscape management tool. ${ }^{16}$ Some of the purposes for burning were to manage bison food resources, to promote berry and root crops, to renew growth in wetlands, to remove forage before winter on enemy hunting areas, to make trails through brush, and to improve habitat for waterfowl and muskrats. There is much still to be learned about how aboriginal groups managed prairie grasslands.

A high proportion of the bison on the prairies were slaughtered between 1791 and 1873. During this 82-year period, there were about 55 years of drought on the northwestern plains. ${ }^{5}$ These droughts reduced the available supply of water and forage and had an effect on both the human and animal predators that relied on them. The heavy reliance on the bison by the aboriginal peoples of the prairies was well known by the nonaboriginal peoples, and hunting of buffalo to deny the food and economic benefits of the herds to the aboriginal communities was deliberately undertaken by the encroaching Europeans. ${ }^{10,11}$ In the American plains the army even supplied white hunters to facilitate the extermination of bison to assist in efforts to force native peoples onto reservations. ${ }^{10,11}$ The combined effects of drought and the excessive bison harvests by these buffalo hunters decimated the bison herds nearly to extinction.

\section{Canada's Prairie "Colony"}

In 1870 the fledgling country of Canada, that included only the four eastern provinces and the new province of Manitoba, purchased Rupert's Land from the Hudson Bay Company for 300,000 pounds sterling. They assumed ownership of this part of British North America's prairies during a period when Americans were quickly spreading westward and potentially northward. Canada and Britain were concerned that the United States might expropriate the lands north of the 49th parallel. ${ }^{17}$ When Canada purchased the northern prairies and adjacent lands, neither sound resource management, as it is currently understood, nor the will of the people residing on the land was a consideration. ${ }^{18}$ Rather, the eastern provinces of Canada saw the prairie region as the natural expansion of their territory. George Brown, one of the fathers of Confederation, described it as "the vast and fertile territory which is our birthright - and which no power on earth can prevent us occupying." ${ }^{19}$

The government of Canada did not follow established British constitutional practice of ceding control of natural resources to the new governments of the prairies. ${ }^{18}$

Thomas indicated: "The Dominion Government exercised all the prerogatives of imperial authority and the Department of the Interior was a veritable colonial office in its relations with western and northern Canada." ${ }^{20}$ There was serious resentment in Alberta, Saskatchewan, and Manitoba toward the central government managing their lands. ${ }^{21}$ The constitutional rights of the local governments were not a consideration.

The lack of recognition by Eastern Canada of the land rights and political rights of aboriginal and Metis peoples during the transfer of land ownership from the Hudson's Bay Company caused both the Red River Rebellion in 1869-1870 and the Northwest Rebellion in $1885 .{ }^{18}$

The federal government retained ownership of the natural resources and Crown (public) lands of the three Prairie Provinces until 1930. This policy decision transformed Canada into a federation of five equal provinces (Ontario, Quebec, Nova Scotia, New Brunswick, and British Columbia) and effectively made a "colony" of the Canadian prairies. ${ }^{17}$ The first federal minister of the Department of the Interior, Alexander Campbell, referred to his new position as that of "Secretary of the Colonies."22 The Department of the Interior was created to administer the Dominion Lands Act (1872). The officials removed native peoples from the open plains and settled Metis land grievances. The land was surveyed and subdivided; then a massive immigration campaign was initiated to attract settlers to the prairies. From the 1870s to 1930, the Department of the Interior managed an orderly "development" and permanent settlement of the Canadian prairies.

As the Canadian prairies were settled, the political and economic goals of the Canadian government were of primary importance. "The Dominion of Canada wanted repayment for the 300,000 pounds they paid for Rupert's Land, rather than it being charged against the people of the provinces of Ontario, Quebec, Nova Scotia, and New Brunswick." ${ }^{17}$ The historian Friesen stated:

\footnotetext{
The millions of acres of western real estate were expected to serve the interests of "Old Canada." After all, the 3.5 million citizens of the four eastern provinces (in 1871) had paid for the land. ... Their hopes lay with the pioneer farmer who would initiate an economic takeoff, by buying lumber, groceries, and agricultural implements on the one hand and shipping grain on the other. To encourage western settlement, a railway must be constructed. ${ }^{23}$
} 
In order for the prairies to produce the resources the Canadian government wanted, settlement of farmers and the subsequent establishment of an annual crop agriculture, particularly wheat, was a primary goal.

\section{Prairie Immigrants 1871 to 1930}

Most of the immigrants who settled the Canadian prairies were from eastern Canada, the United States, and Europe. Were these people well prepared for the rigors they were about to experience as homesteaders on the prairies? The local conditions, vagaries of weather, soils, and ecosystems were not well understood by the new settlers.

From 1871 to 1896 , Canada attracted few immigrants to the prairies due to an economic depression and competition from the United States for immigrant farmers. In 1896 the newly elected government appointed a dynamic new Minister to the Department of the Interior. Clifford Sifton, a lawyer from Manitoba, soon radically shook up his department by trimming red tape so that homesteads could be acquired quickly. ${ }^{24,25}$ The immigration branch was streamlined and became more efficient. Immigrants to the prairies increased Canada's population by $40 \%$ from 5 million in 1900 to 7 million in 1910. The Department of the Interior wanted farmers as immigrants, and they advertised in Britain, the United States, and Europe. Millions of brochures were sent out; advertisements appeared in many newspapers; and foreign journalists were wined and dined. ${ }^{26}$ The primary attraction to the settlers was large areas of land available at a low cost. Minister Sifton, however, also suppressed information about how long and cold the prairie winter was. The climate was described as being comparatively agreeable. ${ }^{26}$

\section{Attitudes Found in British History toward Natural Vegetation}

In Britain, the shift from the hunter-gatherer land management style declined starting about $4000 \mathrm{BC}$ when immigrants arrived from Europe bringing new tools and agricultural technology. ${ }^{27}$ As they displaced the original peoples, these immigrants developed an agriculture that depended upon cleared farmland, cereal crops, and domestic animals. The new technology required an increased dependence on cultivated agriculture. ${ }^{28}$ Soil fertility was not maintained, however, and every 10 to 20 years the human groups had to move away from the depleted soils, chop down new woodlands, and re-establish cultivated fields on the more fertile soils that underlay the native woodlands.

The Romans had a marked influence on both Britain and Gaul (France); they caused a dramatic shift in attitude towards native vegetation. ${ }^{29}$ Romans were afraid of the expansive, dark, natural woodlands. The highly disciplined soldiers were not comfortable when fierce tribesmen ambushed them from the dark woodlands. The Romans considered the forest to be the antithesis of civilization. Part of the Roman changes to the northern European landscape involved the elimination of many native woodlands and the establishment of large areas of planted crops. ${ }^{27-29}$

Early British land management was exploitive of the natural resources. ${ }^{27,30}$ The natural resources were treated by both nobility and commoners as being limitless; sustainability was not a consideration at that time. Overgrazing of woodlands was a common practice. The wild woods were cleared systematically to increase the food supply of an ever-expanding human and domestic livestock population. It took the Black plague during the Little Ice Age in the 13th century to kill enough people to force a revision in agricultural practices; as a result, these practices became more ecologically sustainable. ${ }^{30}$ Intensive cultivated agriculture was no longer possible due to the death of much of the labor force. This change in population and land use halted degradation of the soil. For about a century, more grasslands were established to feed livestock, and gradually the soil fertility improved.

For several thousand years of British and European history, the common idea existed that agricultural land must be cultivated, planted, and harvested in order to be valuable. Within British agriculture, the perception of natural vegetation, whether it was grassland, wetland, or forest, was considered unattractive and worthless, except for the potential for a monetary return. ${ }^{27,31}$ This concept was brought into Canada and the United States when British and European farmers immigrated to North America, as well as to other parts of the world.

In Canadian agricultural circles, and at Statistics Canada, the concept of "improved land" refers to cultivated land and "unimproved land" refers to land that is not cultivated. ${ }^{32}$ Natural grasslands were included in Statistics Canada documents as being "unimproved land." There was an assumption that "improved" crop plants are developed for specific purposes and are assumed to be superior to other strains or species. Mechanical tillage, "improved" crop plants, fertilization, liming, and weed control were traditions in British and European agriculture before settlers immigrated to North America.

Soil scientists often use the soils under natural grasslands as the controls when studying the effects of cultivation on the agricultural ecosystem. ${ }^{33}$ Nevertheless, it is still popular to consider the natural grasslands as "unimproved" and the cultivated land as "improved." Often, the soils under natural Great Plains grasslands have a higher level of organic matter and are more fertile than adjacent cultivated soils. ${ }^{33}$

The idea of keeping natural grasslands and managing them on a sustainable basis would have been foreign to most immigrant farmers. The average homesteader would have followed the instructions of the Department of the Interior to quickly plow up the natural grasslands and plant wheat or other grains. The natural grasslands would have been considered "unimproved land," even though their draft horses depended upon them for grazing 12 months of the year. Thus, most native grasslands on the level plains were 
plowed so that "improved" crops could be planted to make a "useful" contribution to the cash flow of the settler family. Most immigrant farmers of 100 years ago would have had no experience or exposure to the wise management of natural grasslands. Probably only a few settlers would realize that natural grasslands were ideal grazing lands for horses and cattle.

In the 1850s James Hector of the Palliser expedition observed how fat the party's horses became as they wintered on plains rough fescue (Festuca hallii) grasslands in the parklands of central Alberta. ${ }^{13}$ Studies have shown that cattle can gain about $0.8 \mathrm{~kg}$ per day grazing these grasslands in late fall, and $1.5 \mathrm{~kg}$ per day in spring.

\section{Land Management Policies in the Settlement Era}

The findings of the British-funded Palliser Expedition during the $1850 \mathrm{~s}^{13}$ were essentially ignored by Dominion of Canada politicians and discounted by the botanist and settlement promoter John Macoun. ${ }^{34}$ The Palliser Expedition experienced the prairies during a prolonged drought and pronounced large areas of the semiarid regions, particularly in the Dry Mixed Grass prairie ecoregion, as unsuited for crop agriculture. ${ }^{13}$ Macoun had assessed the Canadian prairies during a wet cyle of years in the 1880s after the bison had been extirpated, and the ungrazed grasslands were very vigorous. Macoun considered the prairies ideally suited for crop agriculture. ${ }^{34}$

British agriculture had little regard for wildlands. ${ }^{29,27}$ Europeans assumed that cultivation was required to "improve the land." Macoun considered the native grasslands as "wasteland," and of little value. ${ }^{34}$ To this day, some of that tradition continues on the Canadian prairies where many farmers favor introduced grains, oilseeds, and tame perennial forages over hardy, productive, native grasslands. Other farmers and ranchers value and manage the native grasslands because they are nutritious for livestock and wildlife, and they are drought tolerant.

The Department of the Interior gifted the settler homesteaders free land with strings attached. There were strict requirements that the settler reside on it and that they cultivate a large portion of the free quarter-section (160 acres) before receiving title to the land. ${ }^{17}$ Other land nearby could be purchased. The settlers were familiar with annual crops and perennial forages, but many had no experience managing the natural grasslands their horses and cattle depended upon for grazing and hay.

The Dominion Lands Act of 1872 opened cultivatable land to homesteaders, with some lands being reserved for school divisions, the railways, and the Hudson Bay Company. ${ }^{17}$ Today, few question the merits of large acreages of grains, oilseeds, and other annual crops being grown on the arable prairie lands. The problem was that inexperienced administrators, as well as the scientist Macoun, often did not know what land was arable and what was not. ${ }^{34}$ The implementation of a national policy, which required settlement and cultivation of native grassland soils that were unsuited to annual crop agriculture, created enormous ecological and social disruption, frequent settler abandonment, and family failure. Severe wind-blown soil erosion started in 1917, and it became rampant in the drought of the 1930s. ${ }^{35}$

There was needless destruction of diverse native grasslands growing on sandy, rocky, saline, shallow, and infertile soils, as well as in drought-prone areas such as the Dry Mixed Grass ecoregion. The droughts revealed that these areas were only suitable for grazing and the conservation of natural grasslands and their associated wildlife. During the 12-year drought of the 1930s, topsoil blew away, soil salinization occurred, soil organic matter declined, nutrients were lost, and natural carbon sequestration was undone. Large portions of the Dry Mixed Grass prairie ecoregion that had been cultivated became a dust bowl.

During the prairie settlement era, the actions of policy makers contributed to the permanent alteration of an estimated 5 to 10 million ha of natural grasslands that grew on soils unsuited to crop agriculture. ${ }^{4}$ These productive rangelands should have remained as natural grasslands that were suitable for ranching, military bases, parks, conservation areas, and national heritage sites.

The drought of the 1930s created a social and ecological disaster for crop farmers and the soils they cultivated. Entire municipal districts were disrupted by settlers abandoning homesteads in the driest regions of the prairies. In 1935, an act was passed in Ottawa, and the Prairie Farm Rehabilitation Administration (PFRA) was formed to address reclamation of abandoned land and management of these fragile lands. ${ }^{36}$ In 1938, Alberta passed the Special Areas Act to establish the Special Areas Board, a provincial crown agency that would manage the affairs in a 1.2-million-ha region (www. specialareas.ab.ca/Appendix1_final3.pdf). This board was needed because "Broad land use control powers are still needed due to the fragile and sensitive nature of these lands." This period was called the "Dirty Thirties" for good reason. A dustbowl was created when the topsoil was blown off cultivated land. Jones described the dry land areas most affected as an "Empire of Dust." ${ }^{35}$

The Canadian federal bureaucracy was slow in accepting that certain areas of prairie grassland were not suitable for crop agriculture, but that they were good lands for ranching. ${ }^{17}$ Grazing leases for settlers were authorized in the First Dominion Land Act of 1872 and were revised in 1876, 1881, 1887, and 1905. Grazing leases were granted to ranchers subject to cancellation with 2 years' notice if the lands were required for agricultural settlement. ${ }^{17}$ It was not until 1905, 35 years after settlement began in Manitoba, that closed leases were introduced for certain areas deemed unfit for "normal" crop agriculture settlement. The areas were often in the Dry Mixed Grass ecoregion, also known locally as the Palliser Triangle, of southeastern Alberta and 
southwestern Saskatchewan, or in the southern Alberta foothills. Leases were to be granted only subject to an official report by the Inspector of Ranches that the land was unfit for "normal" agricultural purposes. ${ }^{17}$ Even in 1905, the Department of the Interior officials interpreted the terms "normal settlement," "normal agricultural purposes," and "agricultural purposes" to be linked to crop agriculture terminology that was applicable to humid southern Ontario, Quebec, and the Maritime Provinces, not to what existed on the Canadian prairies. Ranching was the appropriate "normal land use" for the Dry Mixed Grass ecoregion of southern Saskatchewan and Alberta, but distant administrators did not comprehend.

While the various levels of government struggled to come to grips with the devastation following the 1930s drought, much abandoned cropland went through a series of stages of plant succession as adapted native species reclaimed the land and stabilized the soil surface from erosion. Dormaar and Smoliak estimated that it would take more than 55 years to restore the soil on abandoned cropland to a state found under native grasslands. ${ }^{33}$

Some crop farmers and ranchers still believe that introduced grass monocultures produce more forage than do native species. Traditionally, the replacement of Mixed Grass prairie by non-native crested wheatgrass and Russian wildrye grass was considered an improvement. ${ }^{37}$ However, recent research has questioned these assumptions. Jefferson et al. suggest that these sentiments of farmers and ranchers need to be re-examined in the light of new knowledge that is developing from ongoing research projects. ${ }^{38}$ In the first 4 years of newly seeded stands, Schellenberg found no differences in forage production between introduced and native grasses. ${ }^{39}$ Willms et al. reported the findings for a 13-year study on the annual forage production of ungrazed native range, harvested native range, seeded crested wheatgrass, and seeded Russian wildrye grass in the Dry Mixed Grass and Mixed Grass prairie ecoregions of Alberta. ${ }^{40}$ The introduced grasses were planted into recently cultivated native grassland soils. The study lasted for 12 years on Brown soils and for 13 years on Dark Brown soils. Crested wheatgrass produced the same amount of forage as ungrazed native grasslands for half of the time, and more herbage for the other half of the time. In contrast, Russian wildrye grass produced less herbage on Dark Brown soils most years and about the same on Brown soils as native grasslands. The highest herbage production of both introduced grasses was in years 2, 3, and 4. That was probably in response to the effects of soil mineralization following cultivation. Willms et al. concluded that "the belief that seeding native grassland to introduced agronomic species would increase forage production was not supported." 40

Given the results of research comparing the forage production of introduced versus native grasslands, the question of the elimination of any more of the residual natural grasslands must be raised for the Mixed Grass and Dry
Mixed Grass ecoregions. Furthermore, Dormaar et al. found that crested wheatgrass and Russian wildrye monocultures reduced soil quality due to increased nutrient export, reduced energy flow, and decreased organic matter input. ${ }^{37}$ This leads to reduced carbon sequestration. They argued that forage breeding had eradicated the sustainability characteristics of these introduced grasses. The authors recognized the value of these introduced forages to the livestock industry but recommended that limits placed on acreages seeded since soil sustainability is ultimately of more value than short-term forage production.

During the settlement era there was much experimentation by government policy makers and settlers. It took 50 million years for the natural grasslands to evolve, adapt, and become sustainable. It took less than 50 years to destroy $80 \%$ of the acreage, about 50 million ha of natural grasslands. Federal policies that had worked well in the high rainfall, temperate climates of eastern Canada where drought was rare were not appropriate for the Canadian prairies. The central government of the day did not understand the serious consequences of periodic prairie droughts.

\section{Climate Change, Change in Land Use, and \\ Crop Agriculture}

Global warming has occurred on the Canadian prairies, and some of it can be attributed to a change in land use. Cultivated soils, exposed all winter long to incoming solar radiation, may absorb more heat than does the light-colored landscape of natural grasslands. A general warming trend over the past century has been compounded across the Canadian prairies by a century of land-use changes. ${ }^{41,42}$ The average increase in surface minimum temperature due to land-use changes is approximately $1^{\circ} \mathrm{C}$ to $1.5^{\circ} \mathrm{C}$. Akinremi et al. argued that the Canadian prairie region may be unique in its response to climate change because of the effects of large-scale changes in land use. ${ }^{43}$ The cultivation and thus removal of 50 million ha $(80 \%)$ of the prairie natural grasslands, and their replacement with annual cereal crops, has contributed to a rise in temperature in the region. Raddatz and Cummins indicate that there is a greater frequency of tornadoes after such a major change in land use from grasslands to mostly annual crops. ${ }^{44}$

\section{History of Ranching}

The first cattle brought to the Canadian prairies were a bull and yearling heifer named Adam and Eve, brought from England via Hudson Bay by boat and canoe to the Selkirk Settlement along the Red River in 1813..$^{45,46}$ Others followed from Europe and the United States. Cattle arrived in Alberta and Saskatchewan by the late 1870s. ${ }^{47,48}$

Livestock production began to expand in the eastern prairies in the 1860s in Manitoba and in the 1880s in southern Saskatchewan and Alberta. In 1881, there were 9,000 head of cattle, mostly of British breeding, in the Northwest Territories, as the region was known prior to the formation 
of Manitoba (1870), Saskatchewan (1905), and Alberta (1905). By the 1890s, when the railroad had reached the major centers of southern Alberta and southern Saskatchewan, the numbers of cattle had expanded to 50,000 in the Palliser triangle. ${ }^{49}$ Most of the cattle were trailed from Oregon and Texas. In what is termed the golden age of ranching (1901 to 1906 ) cattle numbers went from 212,145 to 360,236 in Saskatchewan.

Cattle were not the only livestock found on the range in plentiful numbers. Scattered throughout southwest Saskatchewan large bands of sheep could be found. For example, Louis Chartrand of Willow Bunch, Saskatchewan, started with 50 animals in 1889 and eventually reached a flock size of $12,000 .{ }^{49}$

The cattle-ranching industry in western Canada in the late 1880s was typically a low-input, extensive grazing operation. In southern Alberta, cows grazed all year, fending for themselves against predators and periodic deep snow in winter. Local ranchers considered cutting and storing hay for winter use to be foolish. ${ }^{48}$ During the severe winters of 1886-1887 and 1906-1907, a high percentage of the cattle either starved or froze to death. After those severe winters, more ranchers stored hay and fed it to cattle as needed in winter.

\section{Grazing Management Practices}

Grazing management expertise was in short supply on residual natural grasslands during the homestead era. Horses were allowed access 12 months per year, while cattle were usually turned out after snowmelt in spring. They then grazed from spring until fall when snow covered the grasses. Most settlers were too busy managing cropland to worry about managing the rangeland growing on their "wasteland areas." The residual grasslands normally occupied areas that could not be easily plowed. They included steep coulees, stony, saline, sandy, or shallow soils, or wetlands (riparian) that could not be put into annual crops.

In drier regions of the Mixed Grass prairie, overgrazing and ignorance of the consequences contributed to the dust-bowl effect. As the crop farming practices contributed to climate change, overgrazing of rangelands by livestock caused declines in forage production and the death of many productive grasses, forbs, and sedges. These palatable species were subsequently replaced by unpalatable or lowgrowing plants. Overgrazing also enabled the invasion of certain alien, unpalatable, or grazing-resistant species, such as Kentucky bluegrass and dandelion.

On some prairie grasslands during the settlement era, the absence of livestock grazing helped maintain a higher level of ecological health. On grasslands distant from water or on steep slopes, where livestock rarely grazed, there were healthier grassland stands compared to the overgrazed grasslands closer to water. The absence of grazing on some of these rangelands and the concentration of settler attention on cropland helped preserve these habitats for wildlife and livestock. A higher level of biological diversity would occur on lightly grazed lands that were often considered "wastelands." The greater biological diversity of natural grasslands provided habitat for a wide variety of wildlife, as well as an emergency supply of forage production and habitat during drought. Today, these remnants are often sought out for conservation (preservation) purposes within parks. Other conservation organizations also have holdings of natural prairie grasslands, and frequently they are not grazed by any large herbivores. No grazing results in a high accumulation of littler. This litter will cause shading and a gradual decrease in species diversity and ecosystem health.

\section{Current Management of Natural Prairie Grasslands}

The absence of grazing is not recommended today for most productive natural grasslands because these ecosystems evolved with grazing and are adapted to it. Also, high litter cover creates a fire hazard. Without grazing, and with a dense litter cover, species diversity decreases year by year. Wildlife often benefit from a more diversified habitat under a regime of moderate livestock grazing. Recommended grazing strategies usually include moderate stocking rates and periodic long periods of rest from grazing rather than a complete absence of large ungulate grazing of natural grasslands.

Today, ranchers and livestock farmers often have a combination of forage types for grazing, including some natural grasslands, tame perennial grasslands, annual forages, forested rangelands, stubble crop residues, annual crop windrows, and occasionally irrigated pastures. Some tame perennial grasses, such as crested wheatgrass and smooth bromegrass, can provide quality pasture from spring to early summer. ${ }^{50}$ Forested rangeland is most frequently available and nutritious in midsummer. The ecological health of native grasslands is most favored by late summer, fall, and winter grazing.

Brush encroached into thousands of hectares of the most fertile soils covered by mesic grasslands, northern parklands, foothills fescue, and Tall Grass prairie after white settlers stopped prairie fires. Carefully managed prescribed burns followed by specific kinds of grazing practices can reduce brush encroachment and stimulate healthy grasslands. ${ }^{51}$ Many brush species are palatable and can be economically used as forage, thus reducing grazing pressure on grasslands. In contrast, some mechanical and herbicide practices to reduce brush may not be economically feasible. ${ }^{52}$

Unique management challenges occur in various prairie natural grassland ranges. The Canadian military has four large training bases; they are mostly composed of natural grasslands and parkland. ${ }^{4}$ Wildlife, some livestock grazing, and conservation are generally compatible with military objectives. Other natural upland grasslands and wetland grasslands are reserved for conservation, waterfowl habitat, and park purposes. Park range managers face real challenges 
to meet conservation objectives and effectively manage large herds of showy, wild ungulates. Left to their own devices, large wild ungulates tend to overgraze preferred areas, leaving them in poor ecological health.

Oil and gas exploration, pipelines, utility corridors, roads, and highways all pass across natural grasslands of the Canadian prairie. In the past, reclamation has favored the use of introduced forage species. Now greater use of native grasses and forbs is developing. More emphasis needs to be placed on protecting these rare natural grassland ecosystems. The oil and gas industry creates some real challenges to land managers wishing to maintain natural grasslands.

In the future, it is likely that there will be more interest in expanding the productive, biologically diverse, hardy, drought-resistant, natural grasslands. ${ }^{4}$ There may also be greater use of local native grasses and forbs for reclamation and reseeding purposes. Canada's prairie will become multiuse in the future as the needs and demands for recreational use, oil and gas, conservation, wildlife, environmental benefits, ecological services, and livestock grazing increase.

Additional information on grazing management in Canada can be found in a new publication, "Management of Canadian Prairie Rangeland," available at www. Foragebeef.ca. This Web site summarizes all applicable forage and beef research in Canada. To find more useful information, go to the section called "Range," subsection "Range Management Basics," subsection "Fact Sheets."

\section{References}

1. Clayton, J. S., W. A. Ehrlich, D. B. Cann, J. H. Day, and I. B. Marshall. 1977. Soils of Canada, Volume 1. Ottawa, Canada: Research Branch, Canada Department of Agriculture. 243 p.

2. Dix, R. L. 1964. A history of biotic and climatic changes within the North American grassland. In: D. J. Crisp [ED.]. Grazing in terrestrial and marine environments. Oxford, United Kingdom: Blackwell Science Publications. p. 71-89.

3. Bailey, A. W. 2000. Future of temperate natural grasslands in the northern hemisphere. In: S. W. L. Jacobs and J. Everett [EDs.]. Grasses: systematics and evolution. Melbourne, Australia: CSIRO. p. 357-364.

4. Bailey, A. W., D. McCartney, and M. P. Schellenberg. (In press). Management of Canadian prairie rangeland. Ottawa, Canada: Agriculture and Agri-Food Canada.

5. SAuchyn, D. J. 2007. Climate change impacts on agriculture in the prairies. In: E. Wall., B. Smit, and J. Wandel [EDs.]. Farming in a changing climate. Vancouver, Canada: University of British Columbia Press. p. 80-93.

6. Dyck, I. 1983. The prehistory of southern Saskatchewan. In: H. T. Epp and I. Dyck [EDS.]. Tracking ancient hunters: prehistoric archeology in Saskatchewan. Saskatoon, Canada: Saskatchewan Archeological Survey. p. 63-139.

7. Boyd, M. J. 2000. Changing physical and ecological landscapes in southwestern Manitoba in relation to Folsom (11,000-10,000 BP) and Mackean (4000-3000 BP) site distribution. In: T. A. Radenbaugh and P. Douaud [EDs.]. Changing prairie landscapes. Regina, Canada: Canadian Plains Research Centre. p. 21-38.
8. Goebel, T., M. R. Waters, and D. H. O'Rourke. 2008. The late Pleistocene dispersal of modern humans in the Americas. Science 319:1497-1502.

9. Binnema, T. 2001. Common and contested ground: a human and environmental history of the northwestern plains. Norman, OK, USA: University of Oklahoma Press. 279 p.

10. Hamalainen, P. 2003. The rise and fall of plains Indian horse cultures. The Journal of American History 90:833-862.

11. Smits, D. D. 1994. The frontier army and the destruction of the buffalo, 1865-1883. Western Historical Quarterly 25: 312-338.

12. Binnema, T. 2006. Allegiances and interests: Niitsitapi (Blackfoot) trade, diplomacy, and warfare, 1806-1831. Western Historical Quarterly 37:327-349.

13. Spry, I. M. [ED.]. 1968. The papers of the Palliser expedition 1857-1860. Toronto, Canada: The Champlain Society. 694 p.

14. Binnema, T. 1996. Presettlement rangeland management on the Northern Plains. Rangelands 18(6):217-218.

15. Fidler, P. 1793. Journal of a journey over land from Buckingham House to the Rocky Mountains in 1792 and 1793. In: B. Haig [ED.]. 1991. A southern Alberta bicentennial: a look at Peter Fidler's journal, 1792-1793. Lethbridge, Canada: Historic Trails West, Ltd. 99 p.

16. Lewis, H. T. 1985. Why Indians burned: specific versus general reasons. In: J. E. Lotan [ED.]. Proceedings, symposium and workshop on wilderness fire. Missoula, MT, USA: USDA Forest Service, Intermountain Forest \& Range Experiment Station GTR-INT 182. p. 75-80.

17. Martin, C. M. 1938. Dominion lands policy. Toronto, Canada: MacMillan. 380 p.

18. Martin, C. M. 1920. "The natural resources question"-The historical basis of provincial claims. Winnipeg, Canada: P. Purell, King's Printer. 148 p.

19. Canadian Broadcasting Corporation. 2001. Canada: a people's history: taking the West 1873-1896, episode 10. Available at: http://history.cbc.ca/history. Accessed 23 September 2010.

20. Thomas, L. H. 1956. The struggle for responsible government in the North-West Territories 1870-1897. Toronto, Canada: University of Toronto Press. 276 p.

21. Thomas, L. G. [ED.]. 1975. The prairie west to 1905: a Canadian sourcebook. Toronto, Canada: Oxford University Press. $360 \mathrm{p}$.

22. Anonymous. No date. Sir Alexander Campbell, Minster, Department of the Interior. Library and Archives Canada. Available at: http://mikan3.archives.ca/pam/public_mikan/ index.php. Accessed 23 December 2008.

23. Friesen, G. 1987. The Canadian prairies: a history. Toronto, Canada: University of Toronto Press. 534 p.

24. Hall, D. J. 1981. The young Napoleon, 1861-1900. Vancouver, Canada: University of British Columbia Press. 361 p.

25. Hall, D. J. 2003. Clifford Sifton. Dictionary of Canadian Biography, Volume 15. Available at: http://www.nrcan.gc.ca/ com/deptmini/traipion/cliffordsifton-eng.php. Accessed 23 September 2010.

26. Brawn, C., And D. Brawn. 2008. Every stone a story: Manitoba's buried history. Winnipeg, Canada: Great Plains Publications. Available at: http://www.manitobasburiedhistory.com. Accessed 23 September 2010. 
27. Rackнam, O. 1990. Trees and woodland in the British landscape. London, United Kingdom: Dent. 234 p.

28. Raскнам, O. 1980. Ancient woodlands: its history, vegetation and uses in England. London, United Kingdom: Edward Arnold. 402 p.

29. ReEd, J. L. 1954. Forests of France. London, United Kingdom: Faber. 296 p.

30. Curtler, W. H. R. 1909. A short history of English agriculture. Oxford, United Kingdom: Clarendon. 371 p.

31. Miles, R. 1967. Forestry in the English landscape. London, United Kingdom: Faber. 42 p.

32. Statistics Canada. 2009. Profile of production trends and environmental issues in Canada's agriculture and agri-food sector: issues in Canada, land use: table 1. Unimproved pasture, area of native pasture, native hay, rangeland, least intensive agricultural land use. Available at: http//www4.agr.gc.ca. Accessed 23 September 2010.

33. Dormanr, J. F., and S. Smoliak. 1985. Recovery of vegetative cover and soil organic matter during revegetation of abandoned farmland in semiarid climate. Journal of Range Management 38:487-491.

34. Macoun, J. 1882. Manitoba and the Great North-West: field for investment; the home of the emigrant, being a full and complete history of the country. Toronto, Canada: World Publishing. $687 \mathrm{p}$.

35. Jones, D. C. 1987. Empire of dust. Edmonton, Canada: University of Alberta Press. 316 p.

36. Anstey, T. H. 1986. One hundred harvests: Research Branch, Agriculture Canada, 1886-1986. Ottawa, Canada: Canadian Government Publishing Center. 432 p.

37. Dormaar, J. F., M. A. Naeth, W. D. Willms, and D. S. Chanasyk. 1995. Effect of native prairie, crested wheatgrass (Agropyron cristatum (L.) Gaertn) and Russian wildrye (Elymus junceus Fisch.) on soil chemical properties. Journal of Range Management 48:258-263.

38. Jefferson, P. G., A. D. IwaAsa, M. P. Schellenberg, and J. G. McLeod. 2005. Re-evaluation of seeding native species for forage/beef production on the semiarid prairie of western Canada. In: T. A. Radenbaugh and G. C. Sutter [eds.]. Managing changing prairie landscapes. Regina, Canada: Canadian Plains Research Center. p. 79-100.

39. Schellenberg, M. P. 2008. Biomass yield differences for introduced versus native grasses in mono- and poly-cultures in Southwestern Saskatchewan. Abstract. In: "Building Bridges: Grasslands to Rangelands" Society for Range ManagementAmerican Forage and Grassland Council Annual General Meeting; 25-31 January 2008; Louisville, KY, USA. Denver, CO, USA: Society for Range Management. Paper No. 2138 [CD-ROM].
40. Willms, W. D., M. Entz, R. Beck, and X. Hao. 2009. Do introduced grasses improve forage production on the Northern Mixed Prairie? Rangeland Ecology and Management 62:53-59.

41. Skinner, W. R., And J. A. Majorowicz. 1999. Regional climatic warming and associated twentieth century land-cover changes in northwestern North America. Climate Research 12:39-52.

42. Raddatz, R. L. 1998. Anthropogenic vegetation transformation and the potential for deep convection on the Canadian prairies. Canadian Journal of Soil Science 78:657-666.

43. Akinremi, O. O., S. M. McGinn, and H. W. Cutforth. 2001. Seasonal spatial patterns of rainfall trends on the Canadian prairies. Journal of Climate 14(9):2177-2182.

44. Raddatz, R. L., and J. D. Cummine. 2003. Interannual variability of moisture flux from the prairie agro-ecosystem: impact of crop phenology on the seasonal pattern of tornado days. Boundary-Layer Meteorology 106:283-295.

45. Deveson, M. 1995. The history of agriculture in Manitoba (1812-1995). Available at: www.manitobaaghalloffame.com/ history2.php. Accessed 23 September 2010.

46. Johnston, A. 1970. A history of the rangelands of western Canada. Journal of Range Management 23:3-8.

47. Kelly, L. V. 1980. The range men. Toronto, Canada: Coles Publishing. 468 p.

48. Brado, E. 1984. Cattle kingdom-early ranching in Alberta. Vancouver, Canada: Douglas and McIntyre. 298 p.

49. Anderson, B. 1988. Beyond the Range: A history of the Saskatchewan Stock Growers Association. Regina, Canada: Saskatchewan Stock Growers Association. 171 p.

50. Murrell, D. 1992. Forage crop recommendations. Regina, Canada: Saskatchewan Agriculture and Food. 16 p.

51. Bailey, A. W. 2008. Prescribed fire: a brush management option. In: R. Moss, B. Gardiner, G. Oliver, and A. W. Bailey [EDs.]. A guide to integrated brush management on the western Canadian plains. Brandon, Canada: Manitoba Forage Council. p. 81-113.

52. Moss, R., B. Gardiner, G. Oliver, and A. Bailey [eds.]. 2008. A guide to integrated brush management on the western Canadian plains. Brandon, Canada: Manitoba Forage Council. $212 \mathrm{p}$.

Authors are Professor Emeritus, Rangeland Ecology, University of Alberta, Edmonton, AB, Canada, awbailey@ualberta.ca (A. Bailey); Rangeland Ecologist, Semiarid Prairie Agricultural Research Centre, Swift Current, SK, Canada (Schellenberg); Retired Forage Beef Systems Research Scientist, AAFC, Lacombe, $A B$, Canada (McCartney); and Cultural Anthropologist, Edmonton, AB, Canada (P. Bailey). 